\title{
The Influence of Situational Leadership and Work Environment towards Employees' Performance
}

\author{
B. Lena Nuryanti S, Rani Rahmawati \\ Universitas Pendidikan Indonesia \\ 229 Bandung, Indonesia \\ lena.nuryanti@upi.edu
}

\begin{abstract}
The background of this research is the employees' low performance, it marked by the revelation assessment result of employees' performance, especially in human resources sector. This phenomenon should soon be dealt with, because employees are one of the factors that can determine the success of a company. Situational leadership and work environment made a way to improve performance. This study aims to (1) find out the description of situational leadership , (2) find out the description of work environment, (3) find out the description of employees' performance, (4) find out the situational leadership effect on employees' performance, (5) find out the work environment effect on employees' performance, (6) find out the influence of situational leadership and work environment on employees' performance in Services and Business Development sector (LPU) of RRI Bandung and 7) find out the relationship between situational leadership and work environment. The object of this research is an employee of Services and Business Development sector (LPU) of RRI Bandung. The research type is descriptive and verification. The method used is the explanatory survey method with 26 people as saturated sampling. Technical analysis of the data used in this research is multiple linear regression with SPSS 21.0 for windows. The results of this research are the situational leadership, work environment and employees' perfomance are in the good category. In the other side, the employees' performance is positively influenced by the situational leadership, while the employees' performance is positively influenced by the work environment and the employees' performance is positively influenced by the situational leadership and work environment, and also there is a positive relationship or correlation between the situational leadership and work environment. Based on the result of this research, it is recommended as the basic for other researchs on training program and career development with different indicators and objects.
\end{abstract}

Keywords-Situational Leadership, Work Environment, Employees Performance

\section{INTRODUCTION}

The low intensity and inaccessibility targets in work caused by low performance quality of human resources. Performance by Veithzal Rivai and Ella Jauvani (2009: 548-549) is "a real behavior which showed by everyone as the performance achievement by employees in accordance with its role within the company". Gomes (2011: 215) explains that the impact of low employee performance is quality and quantity of work produced less than satisfactory and low employee creativity.
According to Martoyo (2000: 115) the affecting factors though employee performance are motivation, job satisfaction, leadership, stress level, work environment, economic aspects, the compensation and physical working conditions. While Saeed, Rashid et.al (2013: 7) states that there are several independent variables that affect the employee's performance such as work environment, organizational culture, reward and personal relationships and conflicts in the work. Furthermore, according to some experts of other factors that affect the performance are the locus of control (Baron and Byrne; 1994), goal orientation, task complexity, leadership style (Fleishman in Peters; 1962), work environment (Weiss, 1999 and Bamberger 2011) and compensation (J. Long 1998: 8).

From some factors mentioned above, leadership style and work environment affect employee performance. Leadership itself according to Robbins and Coulter (2012: 461), "Leader is someone who can influence others and who has managerial authority". The means that the leader is someone who can influence others and who has managerial authority. Robbins and Judge (2013: 368) defines, "Leadership as the ability to influence a group toward the achievement of a vision or set of goals". Previous research about the radio shown that there were leadership problems which resulted in lower satisfaction and resulted in a drop of performance in radio organization ( Wicaksono; and Ayu Kartika 2013; 2012). The ideal leadership style for employees will create an atmosphere and good working conditions, and will lead to job satisfaction for employees.

According to Supardi in Subroto, (2005) "working environment is around the workplace for physical and nonphysical that can give the impression of a pleasant, secure, convenient, and comfortable to work. General overview of work environment in RRI Bandung itself is quite cover the terms of physical and non-physical environment. Among them are the physical facilities such as tools that support for working, although using the technologies without hi-tech, yet hygiene condition, health and convenient in working atmospheres was already good. Just need to be improved the organizational relationships among employees and technology tools that supported in motivation and social relationships such as teamwork, supervisors and subordinates need to be improved.

If seen from the observations made in RRI Bandung, the working environment contained in RRI Bandung is well include the terms of physical environment and non-physical environment. Among them are the physical facilities such as tools that support the work, although using the technologies without hi-tech, yet to hygiene conditions, health and convenient 
in working atmosphere was already good. Other dimensions such as noise, the working environment in RRI Bandung includes a fairly comfortable and conducive working environment in RRI Bandung. The level of lighting in some areas of work need to be considered again given good lighting effect on the physical condition for the employee. Temperature and air circulation are good enough. The problem, however, needs to be increased the socialization relationship among employees and technology tools that support the performance. Non-physical relationships such as teamwork, supervisors and subordinates need to be improved.

RRI strategy in 2015 in improving performances: 1) improving the good communication between staff members; 2) giving freedom to employees to create work space as comfortable as possible for them; 3) make the vision and the same dream, because when all employees have the same dreams and goals, then each step that they will support each other through to the end of their major objectives can be achieved; and 4) the positive support from RRI Management, Head of Division and Head of Department. This is related to the welfare of employees and working regulations that must be obeyed with employees. Company regulation which is mutual benefit and employee welfare which is guaranteed to be one of significant motivation to increase the motivation of employees.

Based on the above phenomenon, need to be required research to solve the problem regarding: "the influence of Situational Leadership and Working Environment toward Employee Performance of Business Development and Services in RRI Bandung".

\section{LITERATURE}

\section{A. Situational Leadership}

Situational leadership according to Fiedler in Gibson, Ivancevich, Donnelly, Konopaske (2012) is a leader contribution toward the effectiveness of group performance depends on way or leadership style and the favorableness of the situation which it faced. According to Fiedler, there are three main factors that affect the suitability of the situation and these three factors are affects to effectiveness of leaders. These factors are leader-member relations, the task structure and position power. According to this leadership model, there are three main variables that likely to determine whether the situation profitable for the leader or not. All three main variables are: leader personal relationship of the group members (leader-member relations); level of tasks structure assigned to the group to be implemented (the task structure); and the power and authority of the position held (position power).

Situational leadership indicators used in this research was the LPC (Least Preferred Coworker) is a way to measure whether a person is task-oriented or relationship. Then after basic leadership style an individual is assessed through the LPC, Fiedler in Gibson, Ivancevich, Donnelly, Konopaske (2012) defines the factors of leader-member relations, task structure, and position power as a main situational factors that determine leadership effectiveness.

\section{B. Work Environment}

Robbins (2014: 86) explains that the environments are institutions or powers beyond that could potentially affect the organizational performance, the environment are concluded into two, namely general environment and specific environment. General environment is everything outside the organization who have the potential to affect the organization. This environment forms of social and technological conditions. While the special environment is part of the environment that are directly related to the goal achievement of an organization.

Furthermore, according to Fautisno Cardoso Gomes (2013: 26) the influence of working environment is the role and behavior affect to the human resources elements that will have an impact on the working conditions of a person. According to Sedarmayanti (2013: 21) working environment is a whole tools and materials which faces the surrounding environment as a worker, working methods, as well as the arrangement works both as individuals and as a group. Factors affecting the physical working environment according to Robbins (2014: 36) 1) The size of the workspace; 2) Setting the workspace and 3) Privacy. According to Agus Ahyari (2000: 99) working environment consists of non-physical work environment that includes the social environment, social status, labor relations in the office, information systems, and opportunities.

\section{Performance}

Veithzal Rivai and Ella Jauvani (2013: 548-549), Performance is the real behavior displayed by everyone as the performance achievement that is achieved by employees in accordance with its role within the company. Employee performance is very essential point in the company efforts to achieve its goal and become one of the main factors of success in the company.

The stable dividend distribution will increase investors' confidence in investing their funds and rated better than the fluctuation dividend distribution. Stable dividend distribution reflects the stable financial condition, it is also used as a signal of success in the future. Factors that affect dividend policy such as liquidity and profitability as described by Hanafi, M.M. (2004: 375).

Many investors perceive that dividend policy is essential because investors have provided cash to the company in which expectation, finally got rewards namely dividends. Dividends increase or decrease often defined as management trusts about prospect for companies or banks. When companies or banks increasing dividend payments, it is interpreted as expectations of management will be improved performance of companies or banks in the future. The dividend distribution is used as a signal by investors about the prospects and risks of companies or banks in the future.

\section{RESEARCH METHOD}

This research was conducted to obtain the effect of situational leadership and work environment toward employee performance in the field of Business Development and Services at RRI Bandung. This research was descriptive and verification. The research was conducted within 5 years from 2010 up to 2014 , the period of this research was time series. In this research, 
the population and sample was 26 employees in the Field of Service and Business Development which is divided into three sections: 1) Public Service; 2) Business Development and 3) Public Communication using saturated sample technique. The analysis techniques used in this research were multiple regression and hypothesis testing using $\mathrm{t}$ test (partial significance test) and $\mathrm{F}$ test (simultaneous significance test).

\section{RESULTS AND DISCUSSION}

The influence of situational leadership and work environment directly or simultaneous toward performance that is equal to $84.90 \%$, while the influence from other variables not included in this research approximately about $15.10 \%$.

TABLE I. OUTPUT MODEL SUMMARY

\begin{tabular}{|l|c|c|c|c|r|}
\hline \multicolumn{6}{|c|}{ Model Summary } \\
\hline Model & $\mathrm{R}$ & $\mathrm{R}$ Square & Adjusted R Square & Std. Error of the Estimate & Durbin-Watson \\
\hline 1 & $.812^{3}$ & .660 & .635 & 22,084 & 1,909 \\
\hline a. Predictors: (Constant), Lingkungan Kerja, Kepernimpinan Tranformasional & \\
b. Dependent Variable: Kinerja Karyawan & &
\end{tabular}

${ }^{\text {a. }}$ Source: Data processing result in 2016

From Table I, the figures obtained by $\mathrm{R}$ Square for situational leadership and working environment is 0.660 that means the employees' performance in the LPU sector of RRI Bandung influenced by $66 \%$ situational leadership and work environment while $34 \%$ is influenced by other factors. Overview of the situational leadership in LPU sector office of LPU RRI Bandung based on the researcg results conducted is located in quite high category. It is measured from the dimensions consist of (1) the relationship of leaders and subordinates, (2) the structure of the task, (3) power position. The results showed that the implementation of situational leadership is quite good but not optimal. The dimensional position of power is the dimension that has the highest rating in influencing employees' performance with a score of 1720 further dimension leader and subordinate relationships obtained a score of 1455, while the dimension that has the lowest rating in influencing the employees' performance of is the task structure with the score acquisition of 1100 .

Situational leadership is a factor that drives the success of employees' performance because if the employees felt comfortable upon their leader, they will not hesitate in carrying out any duties and loyalty to the company.

2. A description of work environment in LPU sector office of RRI Bandung belongs in enough high score to gain 4,337 or $71 \%$ which is an assessment of its dimensions, they are physical and non-physical working environment. The lowest rate for the physical work environment with score of 1,427 (67.9\%) and non-physical work environment with score of 2,910 (72.9\%). Work environment is an important point that should be considered by the company. This working environment create comfortableness and support employees in performing their task, so that the employees will be satisfied and the work spirit would create good results.

3. A description of employees' performance in LPU sector office of RRI Bandung measured by 1) Competence; 2) The quantity of work 3) Quality of Work and 4) Interpersonal Effectiveness, it is in quite high category with total score of 3899 out of 30 respondents. The rate for each dimensions are Interpersonal Effectiveness with the highest score of 1,332
$(63 \%)$, then Competence with score of 1,184 (70.4\%), followed by Quantity of Work with score of $831(66 \%)$ and the lowest is Quality of Work with score of $552(65,7 \%)$.

4. Situational leadership has a positive influence on employees' performance with a strong degree of correlation equal to $44.2 \%$, it is based on the result of table regression test. This shows that the higher situational leadership percentage, the higher the employees' performance.

5. Working environment has a positive impact on employees' performance to the strong correlation level that is implanted at $48 \%$ based on the result of table regression test. This shows that the higher working environment percentage, the higher the employees' performance.

6. Situational leadership and work environment have a positive influence on employees' performance in the LPU sector of RRI Bandung with a very strong correlation level that is equal to $0.812 \%$. This shows that the higher situational leadership and work environment percentage, the higher the emplyees' performance. According to the result of the coefficient in determination diversity data on situational leadership with work environment that contributes towards the performance in the LPU sector of RRI Bandung is $66 \%$.

The effectiveness of leadership could be seen from superior and subordinate relationships within a company. The level of performance achievement which achieved by group affected by motivation system from the leaders and the extent to which a leader can control and affect a particular situation, it can be said that the success of a leader would occur when the leader adapts its leadership style with maturity of subordinates. In the other side, improving the working environment could be conducted by improving all working facilities, arrangement of work space and creation of good relationships atmosphere between colleagues.

Work environment that will provide the comfortable atmosphere for employees so employees could make a good performance for the company. Lack of convenience in the room can affect the atmosphere decrease of employee in their work then the performance will be low. In addition, non-physical work environment in the field of LPU at RRI Bandung was good 
enough in which relationships for all employees are good especially on manner to be honor to the employees with older age. It can give a good effect on the employee's work.

According to Veithzal Rivai and Ella Jauvani (2009: 548549), Performance is the real behavior displayed by everyone as the performance achievement obtained by employees in accordance with its role within the company. Performance factor be used as measurement of employee performance is directed at four aspects which are key areas of achievement for the company concerned. The key achievements field by GomezMejia, Balkin and Cardy (2012: 225) argued that the dimensions of performance consists of:

- Quality of work

- Quantity of work performed

- Interpersonal effectiveness

- Competencies

Therefore employees in achieving their performance could fulfill the work result in accordance determined by the company (quantity of work), understand and know about the job (quality of work), have good coordination with fellow colleagues (interpersonal Effectiveness) and have the ability or character that would be excellence in work (competence).

\section{CONCLUSION}

The variable of situational leadership and work environment has a positive and significant impact toward employees performance with high enough influence of these two variables mentioned to affect the employees performance in achieving maximum output. This is indicated that the better companies build situational leadership and work environment, then will much better the employee's performance also achieved by RRI Bandung.

The research states that situational leadership and work environment affect positively in improving employee performance, then the author recommend that RRI Bandung have to increase the employee performance by providing adequate facilities and create a good climate for the employees convenience, because it can be decreased motivation for employees if facilities had long been renewed and a lack of privacy in the work room. Additionally, employee performance in the field of Business Development and Services in RRI Bandung could be improved on the quality aspect of work. Should work performed is not limited to reach the target but pay attention to the essence and quality of the work. Therefore, companies should be focus on improving skills and employees professionalism.

\section{REFERENCES}

[1] Gomes-Mejia, L.R., D.B. Balkin, dan R.L Cardy. 2012. Managing Human Resources. Englewood Cliffs: PrenticeHall, Inc.

[2] Susilo M., Manajemen Sumber Daya Manusia, Edisi 4. 2000, $p$

[3] Saeed, Rashed, et.al. 2013. Factors Affecting the Performance of Employees at Work Banking Sectorof Pakistan. Middle

[4] Robbins. Stenhen. P... Coulter. Mary, 2012, Management. Eleventh Edition.p461

[5] Robbins, Stephen P \& Judge, T.A, 2013. Perilaku Organisasi Edisi ke-12, Jakarta: Salemba Empat, p368

[6] Fiedler,F. E,1967 A Theory of Leaderships Effectiveness, Mc Graw-Hill Book Company, New York, p.159.

[7] Sedarmayanti, 2013. Manajemen Sumber Daya Manusia, Bandung: Refika Aditama, p21

[8] Rivai,.V, Manajemen Sumber Daya Manusia untuk Perusahaan. Rajawali Press, 2013, Depok, p548-549

[9] George, J.M.,.Jones G.R.,. Understanding and Managing Organizational Behavior 5th edition, $2011 \mathrm{p}$

[10] James, G.L et.al.,Organizations Behaviour Structure and Processes, 2012

[11] -East Journal of Scientific Research 17 (9): 1200-1208. Sahiwal, Pakistan. 